has visited the Museum as a result of a memorandum outlining a scheme which was presented to the Ministry in 1944, and "It is understood that the Ministry is now in consultation with Local Education Authorities in Wales on the matter". Appendixes at the end of the report include lists of acquisitions, publications by members of the staff during the year, and the usual list of the Museum's handbooks and guides.

\section{Waxwing Immigration}

THE severe winter of 1946-47 was marked in England by an abnormal immigration of waxwings (Bombycilla garrulus) and great grey shrikes (Lanius excubitor), particularly the former. Appearing near Edinburgh in November, flocks of waxwings quickly spread over the eastern counties of England in the latter months of 1946, and in late December appeared in Lakeland, where some flocks of more than twenty birds were noticed. In December and January several birds appeared in Lancashire and Cheshire, near Lancaster, Liverpool, Altrincham and Chester, and as usual in these immigrations the birds were attracted to berry-bearing shrubs and were exceedingly tame. There was a previous immigration of these noticeably brilliant birds into the eastern counties early in 1943; but they do not usually penetrate in such large numbers as occurred during the recent immigration into the western half of Britain. Nesting in North Europe, their irregular visitations to Britain were first recorded near York in 1681 (Phil. Trans. Roy. Soc.). Odd birds occur almost every winter in Scotland, but Irish records are much fewer than those in England.

\section{Proceedings of the Tenth International Congress of Chemistry}

THE full Proceedings of the Tenth International Congress of Chemistry, which was held in Rome in May 1938 under the presidency of the late Prof. Nicola Parravano, were published in five volumes in Italy during the years 1938-39. Owing to the outbreak of war, many libraries in Great Britain and elsewhere will have failed to receive complete sets of this important publication, and they will be glad now to learn that copies of the five volumes are still available. Full particulars may be obtained from Prof. Guido Bargellini, Istituto Chimico, Città Universitaria, Rome, to whom also orders for any of, or all, the volumes should be addressed.

\section{Lord Kelvin and the British Metrical System}

ON June 2, 1897, in his well-known address to the Victoria Institute on "The Age of the Earth", Lord Kelvin said: "I must first ask you to excuse my giving you all my depths, heights, and distances, in terms of the kilometre, being about six-tenths of that very inconvenient measure the English statute mile, which with all the other monstrosities of our British metrical system, will, let us hope, not long survive the legislation of our present Parliamentary session destined to honour the sixty years' Jubilee of Queen Victoria's reign by legalising the French metrical system for the United Kingdom". The Weights and Measures (Metric System) Act was passed, and it is no longer a punishable offence for a tradesman to have in his possession a weight or measure of the decimal system. But with all the "monstrosities of our British metrical system" still surviving, it is interesting to recall the fiftieth anniversary of Lord Kelvin's unfulfilled hope.

\section{Announcements}

DR. T. F. WEST, author of papers on D.D.T., has been appointed an assistant director of the Ontario Research Foundation, and will leave London to take up his duties in Canada in July.

Dr. D. W. Davison, of the physics staff of the Brown-Firth Research Laboratories (Thos. Firth and John Brown, Ltd., Sheffield), has been appointed a senior research officer, Council for Scientific and Industrial Research, Australia, in the Research School of Metallurgy at the University of Melbourne, where he will join a team working on the physies and crystallography of ferrous and non-ferrous metals, under Prof. J. Neill Greenwood.

Sir RoBert Robinson, president of the Royal Society, will open a new research laboratory in the Department of Chemistry, University of Glasgow, on June 25; the laboratory is to bear the name of G. G. Henderson.

As a result of a meeting of mycologists and plant pathologists at the Indian Agricultural Research Institute, New Delhi, on February 28, the Indian Phytopathological Society was initiated. All persons interested in the study of fungi, bacteria and viruses are invited to join the Society. Further information can be obtained from the SecretaryTreasurer, Indian Phytopathological Society, Agricultural Research Institute P.O., New Delhi.

THE report of the Conference on "Research and the Smaller Firm" arranged by the Manchester Joint Research Council last October (see Nature, 158, 638 ; 1946), which has now been published (from the Manchester Chamber of Commerce. 2s. 6d.), includes an account of the proceedings of the Conference with a full report of the discussions at both sessions. The papers by Mr. C. E. Renold, Dr. C. J. T. Cronshaw and Dr. F. C. Toy are appended, with written contributions from Mr. H. Downs and Mr. J. Williams and a note on the Manchester Federation of Scientific Societies.

Detams of the Industrial Film Service of the Blackheath Film Unit (9 North Street, Leatherhead), which has already been responsible for such outstanding films as "Training of the Disabled", for the Ministry of Labour and National Service, and "Sugar Beet", for the Ministry of Agriculture, are outlined in a sixteen-page brochure issued by the Unit. The Unit is equipped and staffed to undertake the production of any type of industrial or instructional film, and can also provide a complete technical service to the film units of its clients.

THe Göteborgs Högskola has awarded the Heyman Prize (value about $£ 700$ ) to Börje Kullenberg, in recognition of his distinguished work in constructing the piston core-sampler, which has provided the means for a new departure in submarine geology. The piston core-sampler has proved capable of securing practically undisturbed sediment profiles up to 20 metres in length. It was used with great success on the Skagerak Expedition to the western Mediterranean during April-May 1946, when long cores were obtained down to a maximum depth of $3,600 \mathrm{~m}$. It will be used from the coming Swedish circumnavigating deep-sea expedition with the Albatross. The Heyman Prize is given at intervals of three years, for literature and for science alternately. In 1941 the first science award was divided between the two eminent Swedish geologists, Helge Backlund and Lennart von Post. 